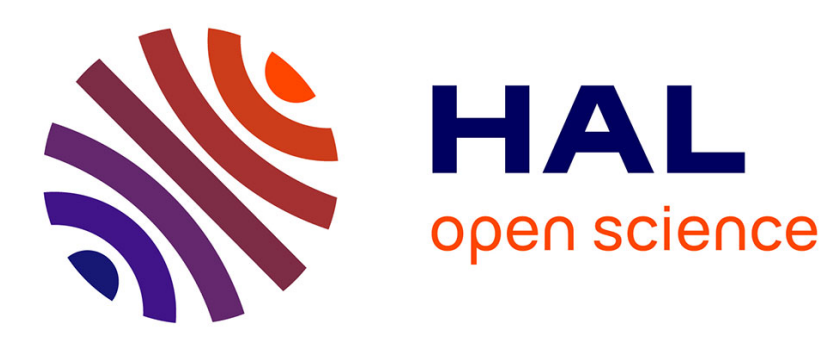

\title{
Management practices increase the impact of roads on plant communities in forests
}

\author{
C. Avon, Yann Dumas, L. Bergès
}

\section{To cite this version:}

C. Avon, Yann Dumas, L. Bergès. Management practices increase the impact of roads on plant communities in forests. Biological Conservation, 2013, 159, p. 24 - p. 31. 10.1016/j.biocon.2012.10.008 . hal-00857231

\section{HAL Id: hal-00857231 \\ https://hal.science/hal-00857231}

Submitted on 3 Sep 2013

HAL is a multi-disciplinary open access archive for the deposit and dissemination of scientific research documents, whether they are published or not. The documents may come from teaching and research institutions in France or abroad, or from public or private research centers.
L'archive ouverte pluridisciplinaire HAL, est destinée au dépôt et à la diffusion de documents scientifiques de niveau recherche, publiés ou non, émanant des établissements d'enseignement et de recherche français ou étrangers, des laboratoires publics ou privés. 
Regular Paper

\title{
Management practices increase the impact of roads on plant communities in forests
}

Keywords: road effect, forest biodiversity, plant communities, skid trails, limestone material, plant dispersal

Catherine Avon ${ }^{a *}$ (catherine.avon@irstea.fr), Yann Dumas ${ }^{\mathrm{b}}$ (yann.dumas@irstea.fr) and Laurent Bergèsa (laurent.berges@irstea.fr)

aIrstea, UR EMAX, 3275 Route CEZANNE, CS 40061, 13182 Aix-en-Provence Cedex 5, France

'Irstea, UR EFNO, Domaine des Barres, 45290 Nogent-sur-Vernisson, France

*Corresponding Author: Tel: +33 442667932, Fax: +33 442669923

\begin{abstract}
The question of the interaction between management practices and road effects on forest biodiversity is of critical interest for sustainable practices and the conservation of forest communities. Forest road improvement and easier access to stand interiors via skid trails, are integral components of management. We tested whether skid trails and the use of limestone gravel for road improvement extended the road effect on plant communities further into forest habitats in a nutrient-poor environment. We analyzed how road distance and skid trail presence affect stand plant communities by examining species composition, distribution of biological and ecological traits, individual species responses and environmental plant indicator values. All results showed that the road effect extended deeper into forest on skid trails, i.e. up to $20 \mathrm{~m}$ and even $60 \mathrm{~m}$, than off skid trails, i.e. up to $10 \mathrm{~m}$. Skid trails served as penetration conduits for open-habitat species probably due to forest machinery traffic. The road effect was more damaging to forest species and less-competitive species on skid trails. Additionally, limestone gravel modified the acidity of adjacent poor soils, leading to a shift in species composition and to a colonization of the stand interior by basophilous species. We advocate minimizing skid trail density and using endogenous materials for roads to keep sections of forest large enough to conserve disturbance-sensitive forest species. The interaction found between road effects and management practices underlines the need to adopt a landscape-scale view and to consider multiple anthropogenic impacts in order to effectively preserve forest plant communities.
\end{abstract}




\section{Introduction}

Transportation infrastructures are now being recognized for their ecological impacts on species and ecosystems, and several reviews have focused on the multiple effects of roads (Benitez-Lopez et al., 2010; Coffin, 2007; Fahrig and Rytwinski, 2009; Forman and Alexander, 1998; Forman et al., 2003; Spellerberg, 1998; Trombulak and Frissell, 2000). However, very few studies have addressed the effects of roads on natural plant communities (Benitez-Lopez et al., 2010). Previous results mainly concern exotic plant dispersal (Flory and Clay, 2006; Gelbard and Belnap, 2003; Hansen and Clevenger, 2005; Parendes and Jones, 2000; Pauchard and Alaback, 2004; Tyser and Worley, 1992) and effects in the immediate vicinity of roads (Mullen et al., 2003; Tikka et al., 2001; Ullmann et al., 1998). Consequently, little is known about the relationship between road distance and global plant communities in adjacent habitats, especially forest habitats. Roads change forest spatial patterns by slicing the forest into pieces, but they also establish new habitats within the forest matrix. This can affect plant species composition by changing soil and habitat properties, and by altering biotic interactions and population dynamics (Forman and Alexander, 1998; Trombulak and Frissell, 2000).

Road construction and maintenance use exogenous materials whose properties contrast with existing soils, as is the case in forests when roads are improved for logging. The addition of lime and clay substrates can modify $\mathrm{pH}$, nutrient content, soil moisture and bulk density and promote the roadside establishment of exotic and nitrophilous species (Greenberg et al., 1997; Johnston and Johnston, 2004; Mullerova et al., 2011). These modifications can extend into the soil and vegetation of many adjacent habitats by the transport of particles by road dust and water runoff (Angold, 1997; Farmer, 1993; Johnston and Johnston, 2004; Mullerova et al., 2011; Tamm and Troedsson, 1955). The phenomenon likely also affects forest habitats, but specific studies are sparse (Dziadowiec et al., 2006; Godefroid and Koedam, 2004). The presence of roads alters other forest habitat conditions such as light and soil moisture levels that, associated with frequent vegetation cuttings and soil disturbances, favor open habitat, exotic and more competitive species (Avon et al., 2010; Buckley et al., 2003; Parendes and Jones, 2000; Watkins et al., 2003), and consequently total species richness is often reported to increase with road proximity. However, this increase does not reflect the loss of certain species like bryophytes, stress-tolerant species and other slow-growing species on roadsides and far into forest stands (Avon et al., 2010). These species are unable to grow in high light and disturbed environments or are displaced by more competitive species (Angold, 1997; Buckley et al., 2003; Hobbs and Huenneke, 1992; Mullerova et al., 2011; Woods, 1993).

Roads can act as dispersal conduits for both exotic and native plants (Birdsall et al., 2012; Greenberg et al., 1997; Parendes and Jones, 2000; Pauchard and Alaback, 2004; Tikka et al., 2001), thus promoting the colonization of adjacent habitats (Gelbard and Belnap, 2003; Hansen and Clevenger, 2005; Tyser and Worley, 1992), especially if they provide favorable environmental conditions. High light and disturbance levels are key factors for open-habitat and exotic species penetration from roads into forests (Avon et al., 2010; Parendes and Jones, 2000; Watkins et al., 2003), and canopy openness together with the disturbances associated to silvicultural treatments and timber harvesting are widely known to impact the vegetation composition of managed 
stands. However, very few studies have attempted to specifically address the issue of the interaction between road effects and management practices in forests, which means the effects of roads on plants in managed forests are probably underestimated. Moreover, studies on the effect of a given management practice on species dispersal from roads have not controlled for road distance (Birdsall et al., 2012; Nelson et al., 2008), which is the most suitable way to measure the influence of management practices on extent of forest road effects (Forman and Alexander, 1998). In managed forests, silvicultural treatments and timber harvesting rely on forest roads, and even more on perpendicular skid trails. Skid trails are created by mowing vegetation during stand regeneration and provide easy access from roads to stand interiors (see Fig. 1). They are evenly distributed across the stands and this is especially the case in lowland managed forests where management is likely to be intense, such as in Europe. Roads and skid trails together can cover a large surface area of forest that offers the conditions of an early-successional habitat during the regeneration of adjacent stands (Avon et al., 2010), after which anthropogenic management on roads keeps them at a permanent open stage. Roads and skid trails are frequently disturbed by the traffic of forest machines and vehicles that can also serve as dispersal vectors for many plants (Decocq et al., 2004; Ebrecht and Schmidt, 2008; Veldman and Putz, 2010). Previous studies have shown that skid trails cause important changes in vegetation communities and can lead to a shift in ground flora from forest interior species to more ruderal, open-habitat or exotic species (Buckley et al., 2003; Ebrecht and Schmidt, 2003, 2008; Zenner and Berger, 2008). We thus hypothesized that skid trails acted as conduits and propagated road effects further into forest, which have not yet been assessed to our knowledge. Forest roads and skid trails are integral components of management and thus of all landscapes with managed forests. The interaction between management practices and road effects on biodiversity is a critical issue for sustainable practices and conservation purposes in forests, at both local and landscape scales, and particularly in the global context of intensified timber harvesting and road networks. We therefore tested whether the forest road effect on plant communities extended further into stands due to management practices in a native nutrient-poor environment. Our main objective was to examine the contribution of skid trails to the road edge effect on understory plants in adjacent stands. Our study zone was composed of young forest stands bordered by limestone graveled roads. Building on our previous results in a different forest context (Avon et al., 2010), we also discussed the road edge effect in terms of the contribution of limestone gravel used for road improvement and stand regeneration.

\section{Materials and Methods}

\section{Study sites}

The study was conducted in an area in the middle of Orléans state forest $\left(48^{\circ} 01^{\prime} \mathrm{N}\right.$, $2^{\circ} 12^{\prime} \mathrm{E}$ ) that covers about 35000 ha and has been managed since at least 1848. Altitude ranges from 107 to $174 \mathrm{~m}$, climate is oceanic, mean annual temperature is about $10.6^{\circ} \mathrm{C}$ and mean annual precipitation is about $700 \mathrm{~mm}$. The study sites were even-aged high forest stands derived from natural regeneration and were mainly composed of sessile oak (Quercus petraea) mixed with less than $25 \%$ Scots pine (Pinus sylvestris). All selected stands were in the first stages of forest succession, from regeneration $(0-2 \mathrm{~m})$ to thicket and thicket-sapling stage $(2-6 \mathrm{~m})$. Soils were acidic $(\mathrm{pH}$ 
$\mathrm{H}_{2} \mathrm{O}<5.5$ ), sandy loams or loamy sands, with depth of high clay content (argic horizon) between 20 to $70 \mathrm{~cm}$, and temporary waterlogging.

\section{Sample design and data collection}

We selected 14 forest stands bordering roads closed to public traffic. The roads have been improved with limestone gravel for forest machinery and logging truck traffic. The limestone gravel layer can reach more than 20 centimeters, and a strong reaction with hydrochloric acid $(\mathrm{HCl})$ was systematically detected on the road verge. Road surface width was about $3.8 \mathrm{~m}$ and total road width averaged $15 \mathrm{~m}$ (Fig. 1). Two transects at a distance of $10 \mathrm{~m}$ apart were established in each stand perpendicular to the road - one off skid trails and the other on skid trails. To facilitate stand access, roadsides and skid trails were frequently managed by vegetation clearings, and soils were disturbed by machinery traffic. We studied the main skid trails that were perpendicular to forest roads, and not the secondary paths used only for hand-applying silvicultural treatments. Skid trails averaged $3 \mathrm{~m}$ in width and covered about $12 \%$ of stand area. Percent canopy cover (vegetation above $2 \mathrm{~m}$ visually estimated ) was null on road verges, averaged $2.5 \%$ on skid trails and $17.8 \%$ off skid trails. We controlled for homogeneous stand conditions and soil type in the transect vicinity as well as in the surrounding landscape (see Avon et al., 2010). Contrary to sites in our previous study, there was no embankment at the road-stand interface. During early summer 2010, $4 \mathrm{~m}^{2}$ plots were established along each transect, i.e. on road verge and at $0,5,10,15,20$, 30 and $60 \mathrm{~m}$ from the road-stand interface (Fig. 1). We recorded the presence of all understory vascular species (pteridophytes and phanerogams) and all bryophytes growing on the soil in the 224 plots. All trees and shrubs less than to $2 \mathrm{~m}$ in height were recorded. The minimum research effort was 7 min per plot, followed by a 5-min rolling period until a new species was found; otherwise research was stopped. Nomenclature follows the French BDNFF (vascular plants) and European BDNBE (bryophytes) systems (Tela Botanica, 2011). Species traits were compiled from Julve (2011) and Biolflor (Kuhn et al., 2004): Raunkiaer's life form and bryophyte type, Grime's plant strategies, dispersal and pollination vector of vascular plants, and a combination of weight and length of seeds. Habitat preference and ancient forest species (Hermy et al., 1999) were also considered. Indicator values of abiotic preferences were obtained for each species from Ellenberg (1992) and Ecoplant (Gegout et al., 2005).

\section{Data analysis}

First, we calculated mean indicator values (miv) for each relevé for light (L), soil moisture $(\mathrm{F})$, nitrogen $(\mathrm{N})$ and acidity $(\mathrm{pH})$, as the arithmetic mean of the indicator values of all plant species found in the plot. These miv are recognized as good predictors of environmental conditions and are widely used in European ecosystem studies (e.g. Diekmann, 2003). We applied a linear mixed-effects model (Ime) using the four miv as dependent variables, road distance, skid trail and their interaction as fixed effects and stand as a random effect. All the effects were treated as factors. Skid trail effect is named "STE" to avoid confusion with the location of relevés (in and off skid trails). We then analyzed which positions along the distance gradient were significantly different in order to determine the depth of road edge influence on the miv. We 
constructed nested models by progressively pooling the eight consecutive distances in seven to two compartments. When the interaction between the two factors was significant, nested models were tested separately for plots in skid trails and plots off skid trails. We used the Ime function of nlme package in $R$ ( $R$ Development Core Team, 2011).

Second, we performed a canonical correspondence analysis (CCA) on the floristic matrix (224 plots $\times 142$ species) to analyze the response of plant composition and used the ade4 package. We used road distance, STE and their interaction as predictors and conducted permutation tests (which were always significant at $p<0.001$ ). We analyzed the 142 species present in at least four plots out of the 216 species collected, as CCA does not work well with very sporadic species. CCA with biplot scaling is known to perform well with unimodal as well as linear response patterns (Ter Braak, 1986). This method allows the discernment of the patterns of species assemblage in communities and clusters species having the same response to the gradients analyzed. These species are assumed to share similar traits, so we verified whether traits were discriminated on CCA biplot. We also verified that the CCA patterns captured community variation well by performing an unconstrained analysis (CA). Then, we examined which positions were significantly different for plant composition. We used the same nested Ime models as above, applying them to the relevé scores on axis 1 of $\mathrm{CCA}$, as this axis was best correlated to road distance.

Third, to identify particular species response patterns, we analyzed individual species responses (presence-absence of a species) with a generalized linear mixed-effects model using road distance, skid trail, and their interaction as fixed effects and stand as a random effect (glmer function of Ime4 package). To avoid model parameterization problems, we selected species with frequency above $10 \%(n=50)$. For all Ime and glmer models, we controlled for normality and homoscedasticity of residuals and used AIC to compare models. All the effects were treated as factors in all analyses.

\section{Results}

\section{Environmental conditions}

Miv.pH, miv.F, miv.N and miv.L were significantly higher in skid trails (Table 1). Miv.pH and miv.N decreased with increasing road distance whereas miv.F only differed at the road-stand interface. When pooling positions in Ime models, analysis showed that miv.pH variation was more gradual and intense than the other miv, and stabilized at 15 $\mathrm{m}$ into the stands. Miv.L only differed on road verges but more strongly on skid trails than off skid trails.

\section{Community response}

Species distribution varied with distance from the road. Forty-five species occurred at all positions. Eighteen species occurred only on the road verge; species accumulation declined with distance from the road, but did not reach a plateau at 60m (Appendix A). Seventy-seven (37\% of the total 216 species) only occurred in the forest stand and were totally absent from the road verge. Total species number was highest at the interface $(n=143)$, but analysis by type of transect revealed that species number on 
the road verge did not differ in and off skid trails and decreased gradually in skid trails but quickly off skid trails. Forty-four species were lost between road verge and $10 \mathrm{~m}$ off skid trails whereas 28 species were lost between road verge and $60 \mathrm{~m}$ on skid trails. Mean species richness displayed the same pattern, with a significant interaction between road distance and STE (Ime analysis not shown).

\section{Constrained analysis}

The complete CCA with road distance $x$ STE as constraints accounted for $11.8 \%$ of the total inertia of the data. The correlation between the constraints and the first two factorial axes was $r^{2}=0.86$ and $r^{2}=0.57$ respectively (the first and second axes explained $5.4 \%$ and $1.8 \%$ of the total inertia respectively). The CCA biplot illustrated that species composition of relevés was well differentiated on the first two axes (Fig. 2). The first axis was primarily associated with road distance and the second with STE (Fig. 2a and 2b). Species composition of road verge was very similar on and off skid trails, but then followed two distinct paths, with a gradual differentiation on skid trails versus an abrupt change off skid trails (Fig. 2c).

The Ime analysis of relevé scores showed that five compartments were discriminated along the distance gradient on skid trails: road verge, interface, the $5 \mathrm{~m}$ position, the 10 $\mathrm{m}$ position, and the 15-to-60 m compartment. This means that the first four positions had a distinct plant composition and that road distance effect penetrated until $15 \mathrm{~m}$ in the forest. However, the CCA biplot showed that species composition at $60 \mathrm{~m}$ differentiated from other positions (Fig. 2d). This suggests that the plant community was not stabilized at $60 \mathrm{~m}$ on skid trails.

Off skid trails, road verge, interface, the 5-to-10 m compartment and the 15-to-60 m compartment were separated by Ime analysis. CCA showed that species composition at the interface clearly differed from the other positions, but thereafter only species composition at $5 \mathrm{~m}$ was distinct (Fig. 2e). Indeed, the analysis of pooled distances using the Ime models detected a change in species composition at $10 \mathrm{~m}$ due to a difference with 15 and $20 \mathrm{~m}$ positions, but the CCA biplot showed that species composition was similar between $10 \mathrm{~m}$ position and 30 and $60 \mathrm{~m}$ positions. This leads to conclude that road edge effect modified plant composition until $10 \mathrm{~m}$ off skid trails.

\section{Differentiation of species community with biological and ecological traits}

The more shade-tolerant species were highly frequent in the stand interior but much less common on the road verge (Fig. 3). The community was not differentiated by soil humidity or nitrogen preference, but strongly discriminated by soil $\mathrm{pH}$ preference: acidophiles were confined to the interior off skid trails whereas basophiles were numerous on roadsides. Considering plant strategies, the species on skid trails and roadsides tended to be more ruderal: CSR, CR, SR and $R$ strategies were absent from the interior off skid trails. Myrmecochorous, barochorous and epizoochorous species were much more frequent on skid trails and on roadsides whereas endozoochorous species were absent from roadsides. Species with short light seeds occurred more often on skid trails and roadsides. Bryophytes, phanerophytes and chamaephytes were absent from the roadside and particularly frequent in the interior off skid trails. Habitat preference also segregated species distribution: forest species avoided road verges 
whereas non-forest species were largely frequent on road verges and skid trails; accordingly, ancient forest species were kept in stand interiors, particularly off skid trails. All these patterns were stronger when considering only species that best responded to factors (not shown). Pollination vector did not discriminate species distribution. Five exotic species were found very sporadically in stand interiors, with a general preference for skid trails.

\section{Individual species response}

Among the species that responded only to STE, five were more frequent off skid trails (group A, Appendix B) and 10 were more frequent on skid trails (group B). Eighteen species avoided the road vicinity (group $\mathrm{C}$ ) and were generally sporadic or even absent from the roadside (Fig. 4a and 4b). Road effect extended up to $5 \mathrm{~m}$ for Agrostis canina, Hedera helix, Hypericum pulchrum, Juncus conglomeratus, Luzula multiflora, $P$. sylvestris, Populus tremula, Rubus fruticosus and up to $10 \mathrm{~m}$ for Deschampsia flexuosa, Dicranum scoparium, Polytrichastrum formosum, Quercus petraea, Veronica officinalis. Road effect clearly modified frequency up to $15 \mathrm{~m}$ for Calluna vulgaris and Carex pilulifera, $20 \mathrm{~m}$ for Hypnum cupressiforme and even $30 \mathrm{~m}$ for Calamagrostis epigejos. In general, species that were affected only up to $5 \mathrm{~m}$ were more frequent on skid trails whereas species showing a deeper extent of road effect were more frequent off skid trails. Eight species had maximum frequency on road verges (group D).

Potentilla reptans and Ranunculus repens did not penetrate far into the stand whereas Brachypodium pinnatum, Centaurea jacea and Hypericum perforatum occurred farther in (Fig. 4c). There was a penetration gradient from the roadside up to $60 \mathrm{~m}$ into the stand for Carex flacca, Dactylis glomerata and Plantago lanceolata; in particular, the frequency of $C$. flacca did not seem stabilized and still reached $18 \%$ at $60 \mathrm{~m}$ (Fig. 4d). Seven out of these eight species were more frequent in skid trails. Five species exhibited a significant interaction effect between road distance and STE (group E, Appendix B). Plantago major, Prunella vulgaris, Taraxacum campylodes showed a strong preference for the roadside off skid trails, whereas in skid trails they were frequent up to $20 \mathrm{~m}$, and even $60 \mathrm{~m}$ for $P$. vulgaris (Fig. 4e). These three species were more frequent in skid trails. Teucrium scorodonia avoided the road verge, especially off skid trails. Viola riviniana avoided the road vicinity on skid trails but the reverse was true off skid trails (Fig 4f).

\section{Discussion}

\section{Skid trails and road effect}

All results showed that the effect of roads on plants was more abrupt and less deep into forest stands off skid trails than in skid trails, even if road verge community was similar in both types. Off skid trails, there was a shift in plant communities between the road verge and the forest stand, after which the variations were smaller. CCA showed that the species composition of forest interior appeared at $10 \mathrm{~m}$, which was corroborated by all results: both mean species richness and gamma species richness stabilized at $10 \mathrm{~m}$, and four out of five species with a significant interaction showed no stand penetration of road effect. Conversely, on skid trails, plant communities changed 
gradually and were affected deeper into the stand. CCA showed a species composition gradient from the roadside up to at least $15 \mathrm{~m}$, and that plant community was still not stabilized at $60 \mathrm{~m}$. The response pattern of mean species richness confirmed the deeper extent of road effect with mean species richness stabilizing only after $20 \mathrm{~m}$. In addition, gamma species richness was still not stabilized at $60 \mathrm{~m}$ and three out of five species with a significant interaction showed road influence up to $20 \mathrm{~m}$ and even $60 \mathrm{~m}$. Roadsides act as early-successional habitats (Avon et al., 2010), and mean indicator values indicated that roadsides offered more nutrient-rich, humid and light conditions than the stand interior. Consequently, roadsides had more ruderal species, and non-forest species were predominant. Like roadsides, skid trails were managed for vegetation growth, and so canopy cover was lower than in the rest of the stand, which explained the higher levels of light, soil moisture and nutrient richness (Ebrecht and Schmidt, 2003). Light conditions on skid trails were close to those on roadsides, as canopy cover was similar in both habitats. The heliophilous and open-habitat species established in the clearcuts thus persisted longer on roadsides and on skid trails but disappeared elsewhere with stand growth (Buckley et al., 2003; Zenner and Berger, 2008). Conversely, less competitive and disturbance-intolerant species (re-)colonized the stand with canopy closure but not skid trails and roadsides. However, there was an additional edge effect of road as suggested by variations in plant community that persisted up to $20 \mathrm{~m}$ and even $60 \mathrm{~m}$ in skid trails and up to $10 \mathrm{~m}$ off skid trails. Our results showed that skid trails were preferential dispersal conduits for roadside species. Consequently, there was a continuum between road community and skid trail community, reflected by an assemblage of shared traits: non-forest species, more ruderal species, myrmecochores, barochores and epizoochores, species with short light seeds, heliophiles and basophiles were predominant on road verges and abundant in skid trails. The colonization can be facilitated by forest machinery traffic along skid trails, which would explain the deep penetration of certain species like $P$. major and P.vulgaris (Berger et al., 2004; Ebrecht and Schmidt, 2003; Schmidt, 1989). The penetration of roadside species can also counteract less-competitive and disturbance-intolerant species, which would explain why we found that these species did not occur on roads and were present farther into skid trails. Forest species and ancient forest species, bryophytes, chamaephytes and phanerophytes, endozoochores, shade-tolerants and acidophiles were favored by the environmental conditions of the stand interior.

\section{Limestone gravel, stand age and road effect}

Our previous study on road effect had been conducted in Montargis forest in older oak stands (20-40 year-old and $>90$ year-old trees) and in a context of infrequent limestone amendments on roads due to the high resistance of the native material (see Avon et al., 2010). The results have shown that the global effect of road stopped at $5 \mathrm{~m}$ (without skid trails). In Orléans forest, species colonizing from the road penetrated farther into stand compared to Montargis (see Avon et al. 2010, and species in common C. flacca, $D$. glomerata, $H$. perforatum, $P$. reptans, $P$. vulgaris and $R$. repens), whereas species affected by a deeply negative road effect reached their forest interior levels farther into stand compared to Montargis (see Avon et al., 2010, and species in common D.

flexuosa, $D$. scoparium, $H$. cupressiforme and $P$. formosum). These differences can be 
explained by stand age or by road surface materials. At Orléans, stands were in early stages of forest succession, and the road edge effect extended farther into the forest. In the regeneration cutting phase, the combination of canopy removal and logging machinery traffic facilitates dispersal from road source, and offers favorable conditions for open-habitat and disturbance-tolerant species (group D). These abiotic conditions disappear rapidly with stand growth, and non-forest species, heliophiles, basophiles and more ruderal species survived near the road, or only on the road verge in older stands. The reverse gradient occurred for forest species, bryophytes, shade-tolerants and acidophiles that slowly re-colonized the stand (group $C$ ) and were present everywhere in adult stands except on the road verge (Avon et al., 2010). Furthermore, at Orléans, the roads were stabilized with a thick layer of limestone whose high $\mathrm{pH}$ decreased the soil acidity of the surrounding nutrient-poor habitat by road dust dispersion and water runoff (Mrotzek et al., 2000; Mullerova et al., 2011). The delivery of exogenous substrate can also introduce exotic and open-habitat species by seed transport within substrate but more probably on dumper trucks themselves, and this dispersal can occur over long distances (Hodkinson and Thompson, 1997; Lonsdale and Lane, 1994; Schmidt, 1989; Wace, 1977). Since limestone amendments and young stand age produced similar patterns, it could be difficult to separate the edge effect caused by one or the other. However, the miv of $\mathrm{pH}$ for roadside, interface and the $5 \mathrm{~m}$ position was higher at Orléans than at Montargis, despite the more acidic forest soils. This conclusively demonstrates that plant species were more basophilous than expected and were able to penetrate into the stand (group D, e.g. C. flacca). Conversely, species avoiding road proximity were more acidophilous (group C, e.g. $\mathrm{H}$. cupressiforme). This suggests that roads improved by exogenous materials had a stronger barrier effect on forest species than native roads (Greenberg et al., 1997). Others studies have also shown stronger impacts of using exogenous (alkaline) materials for road surfacing in nutrient-poor environments (Hobbs and Huenneke, 1992; Johnston and Johnston, 2004; Mullerova et al., 2011).

\section{Combined effects of road and management reduce forest interior area}

The road effect was exacerbated by both silvicultural practices in the early stages of forest succession and by road improvement that used exogenous material. Skid trails are needed for silvicultural treatments but we showed that they served to propagate road effects into the forest interior. Forest managers should pay serious attention to the role played by management and machinery traffic from the outside to the interior of forest, along forest roads and skid trails, on the introduction of open-habitat species. We recommend that road improvement use endogenous materials that do not change soil $\mathrm{pH}$. We also advocate a serious look at the balance between the benefits of new road construction and the negative effects on forest plant communities. Above all, considering the current intensification of logging, it is important for forest biodiversity conservation purposes to strongly limit the density of skid trails and the frequency and duration of skid trail management (Zenner and Berger, 2008). Skid trails covered about $12 \%$ of stand area in our study zone (only main paths), but a broad variation exists in skid trail density among forests. Combined with the road effect zone, skid trails undoubtedly reduce the forest area suitable for forest interior species. 


\section{Acknowledgements}

Funding was provided by the French Ministry of the Environment (MEEDTL) through Irstea - DEB framework agreement (2009-2011, $\left.n^{\circ} 25\right)$.

\section{References}

Angold, P.G., 1997. The impact of a road upon adjacent heathland vegetation: Effects on plant species composition. J. Appl. Ecol. 34, 409-417.

Avon, C., Bergès, L., Dumas, Y., Dupouey, J.L., 2010. Does the effect of forest roads extend a few meters or more into the adjacent forest? A study on understory plant diversity in managed oak stands. Forest Ecol. Manag. 259, 1546-1555.

Benitez-Lopez, A., Alkemade, R., Verweij, P.A., 2010. The impacts of roads and other infrastructure on mammal and bird populations: A meta-analysis. Biol. Conserv. 143, 1307-1316.

Berger, A.L., Puettmann, K.J., Host, G.E., 2004. Harvesting impacts on soil and understory vegetation: The influence of season of harvest and within-site disturbance patterns on clear-cut aspen stands in Minnesota. Can. J. Forest. Res. 34, 2159-2168. Birdsall, J.L., McCaughey, W., Runyon, J.B., 2012. Roads impact the distribution of noxious weeds more than restoration treatments in a lodgepole pine forest in Montana, U.S.A. Restor. Ecol. 20, 517-523.

Buckley, D.S., Crow, T.R., Nauertz, E.A., Schulz, K.E., 2003. Influence of skid trails and haul roads on understory plant richness and composition in managed forest landscapes in Upper Michigan, USA. Forest. Ecol. Manag. 175, 509-520. Coffin, A.W., 2007. From roadkill to road ecology: A review of the ecological effects of roads. Journal of Transport Geography. 15, 396-406.

Decocq, G., Valentin, B., Toussaint, B., Hendoux, R., Saguez, R., Bardat, J., 2004. Soil seed bank composition and diversity in a managed temperate deciduous forest.

Biodivers. Conserv. 13, 2485-2509.

Diekmann, M. 2003. Species indicator values as an important tool in applied plant ecology - a review. Basic Appl. Ecol. 4, 493-506.

Dziadowiec, H., Paszek, I., Cereficki, R., 2006. Plant cover and properties of upper soil horizons in road/forest ecotones in Gorzno-Lidzbark Landscape Park. Polish Botanical Studies. 22, 173-183.

Ebrecht, L., Schmidt, W., 2003. Nitrogen mineralization and vegetation along skidding tracks. Ann. Forest. Sci. 60, 733-740.

Ebrecht, L., Schmidt, W., 2008. Impact of soil seed bank and diaspore transportation by forest machines on the development of vegetation along skid trails. Forstarchiv. 79, 91-105.

Ellenberg, H., Weber, H.E., Düll, R., Wirth, V., Werner, W., Paulißen, D., 1992.

Zeigerwerte von Pflanzen in Mitteleuropa. Verlag Goltze, Göttingen.

Fahrig, L., Rytwinski, T., 2009. Effects of roads on animal abundance: An empirical review and synthesis. Ecology and Society. 14,

http://www.ecologyandsociety.org/vol14/iss1/art21/

Farmer, A.M., 1993. The effects of dust on vegetation - a review. Environ. Pollut. 79, 63-75.

Flory, S.L., Clay, K., 2006. Invasive shrub distribution varies with distance to roads and stand age in eastern deciduous forests in Indiana, USA. Plant Ecology. 184, 131-141. 
Forman, R.T.T., Alexander, L.E., 1998. Roads and their major ecological effects. Annu. Rev. Ecol. Syst. 29, 207-231.

Forman, R.T.T., Sperling, D., Bissonette, J.A., Clevenger, A.P., Cutshall, C.D., Dale, V.H., Fahrig, L., France, R., Goldman, C.R., Heanue, K., Jones, J., Swanson, F., Turrentine, T., Winter, T.C., 2003. Road Ecology: Science and Solutions. Island Press, Washington.

Gegout, J.C., Coudun, C., Bailly, G., Jabiol, B., 2005. Ecoplant: A forest site database linking floristic data with soil and climate variables. J. Veg. Sci. 16, 257-260.

Gelbard, J.L., Belnap, J., 2003. Roads as conduits for exotic plant invasions in a semiarid landscape. Conserv. Biol. 17, 420-432.

Godefroid, S., Koedam, N., 2004. The impact of forest paths upon adjacent vegetation: Effects of the path surfacing material on the species composition and soil compaction. Biol. Conserv. 119, 405-419.

Greenberg, C.H., Crownover, S.H., Gordon, D.R., 1997. Roadside soils: A corridor for invasion of xeric scrub by nonindigenous plants. Natural Areas Journal. 17, 99-109.

Hansen, M.J., Clevenger, A.P., 2005. The influence of disturbance and habitat on the presence of non-native plant species along transport corridors. Biol. Conserv. 125, 249-259.

Hermy, M., Honnay, O., Firbank, L., Grashof-Bokdam, C., Lawesson, J.E., 1999. An ecological comparison between ancient and other forest plant species of Europe, and the implications for forest conservation. Biol. Conserv. 91, 9-22.

Hobbs, R.J., Huenneke, L.F., 1992. Disturbance, diversity, and invasion - implications for conservations. Conserv. Biol. 6, 324-337.

Hodkinson, D.J., Thompson, K., 1997. Plant dispersal: The role of man. J. Appl. Ecol. 34, 1484-1496.

Johnston, F.M., Johnston, S.W., 2004. Impacts of road disturbance on soil properties and on exotic plant occurrence in subalpine areas of the Australian Alps. Antarct. Alp. Res. 36, 201-207.

Julve, P., 2011. Baseflor. Accessed October 2011, available at http://philippe.julve.pagesperso-orange.fr/catminat.htm

Kuhn, I., Durka, W., Klotz, S., 2004. Biolflor - a new plant-trait database as a tool for plant invasion ecology. Divers. Distrib. 10, 363-365.

Lonsdale, W.M., Lane, A.M., 1994. Tourist vehicles as vectors of weed seeds in Kakadu-National-Park, Northern Australia. Biol. Conserv. 69, 277-283.

Mrotzek, R., Pfirrmann, H., Barge, U., 2000. Effect of road construction material and light on the vegetation along the roadsides and adjoining forest using the example of roads in the forest district Bramwald in Niedersachsen. Forstarchiv. 71, 234-244. Mullen, K., Fahy, O., Gormally, M., 2003. Ground flora and associated arthropod communities of forest road edges in Connemara, Ireland. Biodivers. Conserv. 12, 87-101.

Mullerova, J., Vitkova, M., Vitek, O., 2011. The impacts of road and walking trails upon adjacent vegetation: Effects of road building materials on species composition in a nutrient poor environment. Sci. Total Environ. 409, 3839-3849.

Nelson, C.R., Halpern, C.B., Agee, J.K., 2008. Thinning and burning result in low-level invasion by nonnative plants but neutral effects on natives. Ecol. Appl. 18, 762-770. 
Parendes, L.A., Jones, J.A., 2000. Role of light availability and dispersal in exotic plant invasion along roads and streams in the $\mathrm{H}$. J. Andrews Experimental Forest, Oregon. Conserv. Biol. 14, 64-75.

Pauchard, A., Alaback, P.B., 2004. Influence of elevation, land use, and landscape context on patterns of alien plant invasions along roadsides in protected areas of south-central Chile. Conserv Biol. 18, 238-248.

R Development Core Team (2011). R: A language and environment for statistical computing. R Foundation for Statistical Computing, Vienna, Austria. ISBN 3-900051-07-0. http://www.R-project.org/.

Schmidt, W., 1989. Plant dispersal by motor cars. Vegetatio. 80, 147-152.

Spellerberg, I.F., 1998. Ecological effects of roads and traffic: A literature review. Global Ecol Biogeogr. 7, 317-333.

Tamm, C.O., Troedsson, T., 1955. An example of the amounts of plant nutrients supplied to the ground in road dust. Oikos. 6, 61-70.

Tela Botanica (2011). BDNFF (v4.02), BDNBE (v1.00). Accessed October 2011, available at http://www.tela-botanica.org

Ter Braak, C.J.F., 1986. Canonical correspondence analysis: a new eigenvector technique for multivariate direct gradient analysis. Ecology. 67, 1167-1179.

Tikka, P.M., Hogmander, H., Koski, P.S., 2001. Road and railway verges serve as dispersal corridors for grassland plants. Landscape Ecol. 16, 659-666.

Trombulak, S.C., Frissell, C.A., 2000. Review of ecological effects of roads on terrestrial and aquatic communities. Conserv. Biol. 14, 18-30.

Tyser, R.W., Worley, C.A., 1992. Alien flora in grasslands adjacent to road and trail corridors in glacier national-park, Montana (USA). Conserv. Biol. 6, 253-262.

Ullmann, I., Bannister, P., Wilson, J.B., 1998. Lateral differentiation and the role of exotic species in roadside vegetation in southern New Zealand. Flora. 193, 149-164. Veldman, J.W., Putz, F.E., 2010. Long-distance dispersal of invasive grasses by logging vehicles in a tropical dry forest. Biotropica. 42, 697-703.

Wace, N., 1977. Assessment of dispersal of plant species: The car-borne flora in Canberra. Proceedings of the Ecological Society of Australia. 10, 167-186.

Watkins, R.Z., Chen, J.Q., Pickens, J., Brosofske, K.D., 2003. Effects of forest roads on understory plants in a managed hardwood landscape. Conserv. Biol. 17, 411-419. Woods, K.D., 1993. Effects of invasion by Lonicera tatarica L. on herbs and tree seedlings in four New-England forests. Am. Midl. Nat. 130, 62-74.

Zenner, E.K., Berger, A.L., 2008. Influence of skidder traffic and canopy removal intensities on the ground flora in a clearcut-with-reserves northern hardwood stand in Minnesota, USA. Forest Ecol. Manag. 256, 1785-1794. 


\section{A \\ Table and figure legends}

\section{A.1 Table 1.}

Response of mean indicator values to road distance and skid trail effects ${ }^{a, b}$ and averaged values by transect type ${ }^{c}$ and road distance.

Miv STE Distance Interaction IS OS ${ }_{d}^{\mathrm{RV}} 0 \mathrm{~m} \quad 5 \mathrm{~m} \quad 10 \mathrm{~m} \quad 15 \mathrm{~m} \quad 20 \mathrm{~m} \quad 30 \mathrm{~m} \quad 60 \mathrm{~m}$

\begin{tabular}{|c|c|c|c|c|c|c|c|c|c|c|c|c|c|}
\hline miv.pH & $* * *$ & $* * *$ & - & $5.5 \quad 5.1$ & & 6.5 & 5.8 & 5.4 & 5.1 & 4.9 & 4.8 & 4.9 & 4.9 \\
\hline miv.F & $* * *$ & * & - & 5.45 .2 & & 5.3 & 5.0 & 5.3 & 5.3 & 5.3 & 5.2 & 5.3 & 5.5 \\
\hline miv. $N$ & $* *$ & $* * *$ & - & $4.0 \quad 3.8$ & & 4.6 & 4.1 & 4.1 & 3.9 & 3.6 & 3.6 & 3.6 & 3.8 \\
\hline \multirow{2}{*}{ miv.L } & \multirow{2}{*}{$* * *$} & \multirow{2}{*}{$* * *$} & \multirow{2}{*}{ * } & & $I^{e}$ & 6.8 & 6.4 & 6.5 & 6.4 & 6.3 & 6.5 & 6.3 & 6.5 \\
\hline & & & & & OS & 6.6 & 5.7 & 5.8 & 5.7 & 5.9 & 5.7 & 5.6 & 5.9 \\
\hline
\end{tabular}

${ }^{a}$ mean indicator value (miv) for acidity $(\mathrm{pH})$, soil humidity $(\mathrm{F})$, nitrogen $(\mathrm{N})$ and light $(\mathrm{L})$, and skid trail effect (STE)

${ }^{b}$ linear mixed-effects models were compared by AIC. The corresponding $p$-values are shown: ${ }^{*} p<0.05,{ }^{* *} p<0.01,{ }^{* * *} p<0.001$

cplots in skid trails (IS) and off skid trails (OS)

${ }^{d}$ road verge

eaverages for each distance are shown by transect type due to significant interaction 


\section{A.2 Figure 1.}

Sampling design at each forest stand. Plant presence was collected at eight distances, from road verge (RV), up to $60 \mathrm{~m}$ from the road-stand interface (60), on skid trails and off skid trails to investigate the role of skid trails in the road edge effect on plants.

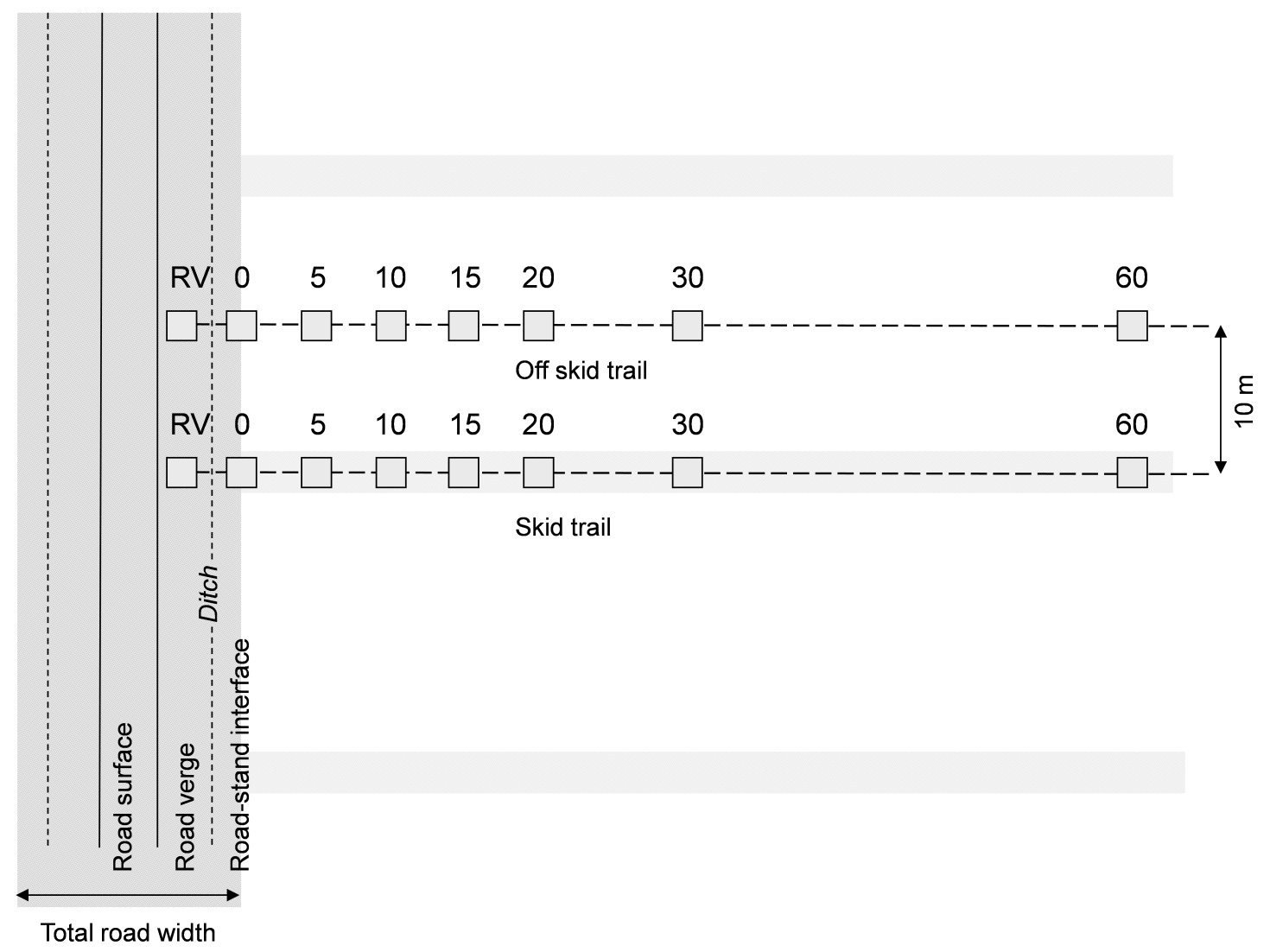




\section{A.3 Figure 2.}

Biplots of canonical correspondence analysis on factorial map $(1,2)$ with road distance $x$ STE (skid trail effect) as constraints on the total data (224 plots), (a), (b), (c), and with only road distance as constraint on plots by transect type (2x112 plots), (d), (e). Plots are grouped (centroids) by road distance class (a), transect type (b), road distance class $x$ transect type (c), and by road distance class in skid trails (d) and off skid trails (e). Road distance classes: road verge (RV), $0 \mathrm{~m}$ (0) to $60 \mathrm{~m}$ into the stand (60); transect types: in skid trails (IS), off skid trails (OS).

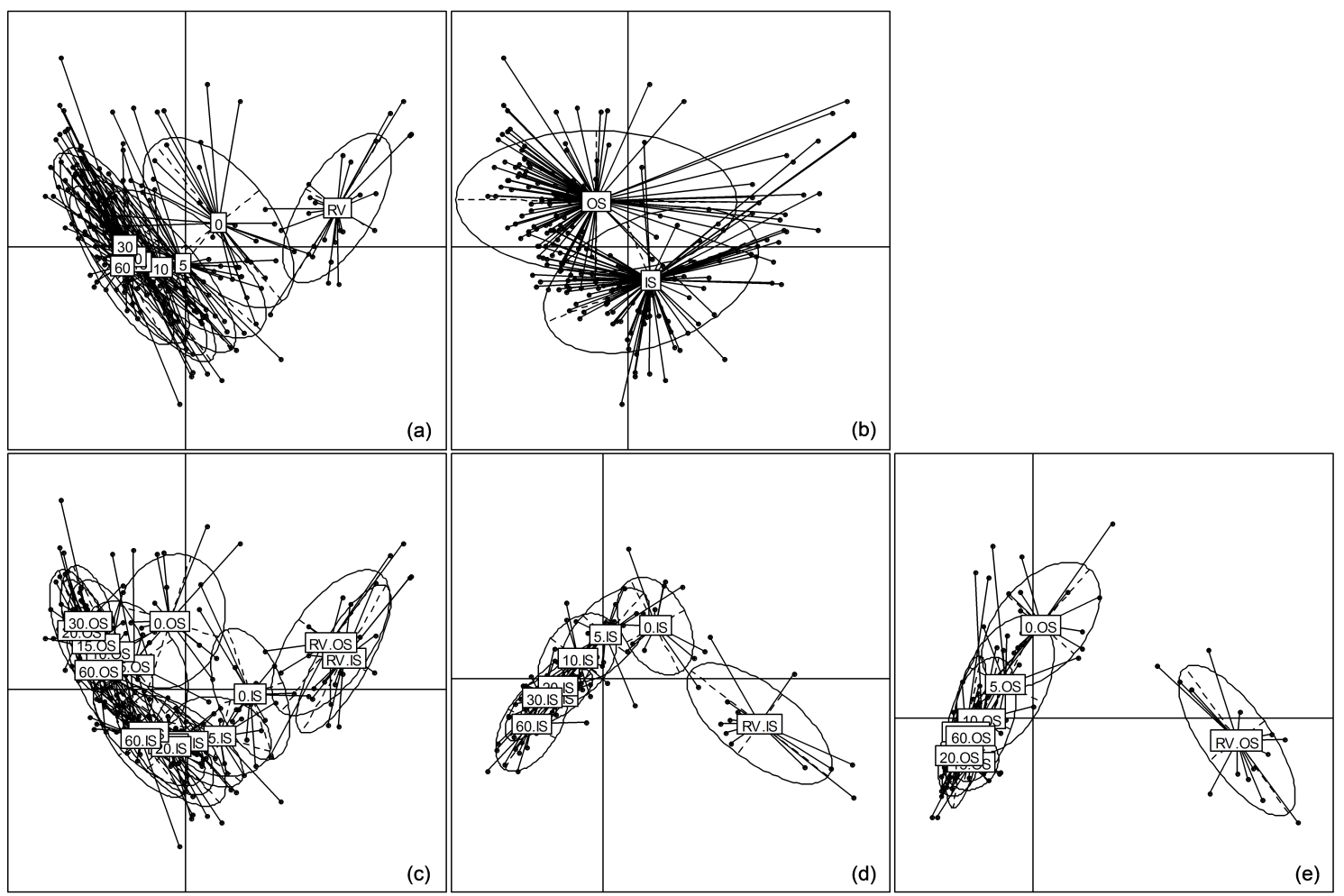




\section{A.4 Figure 3.}

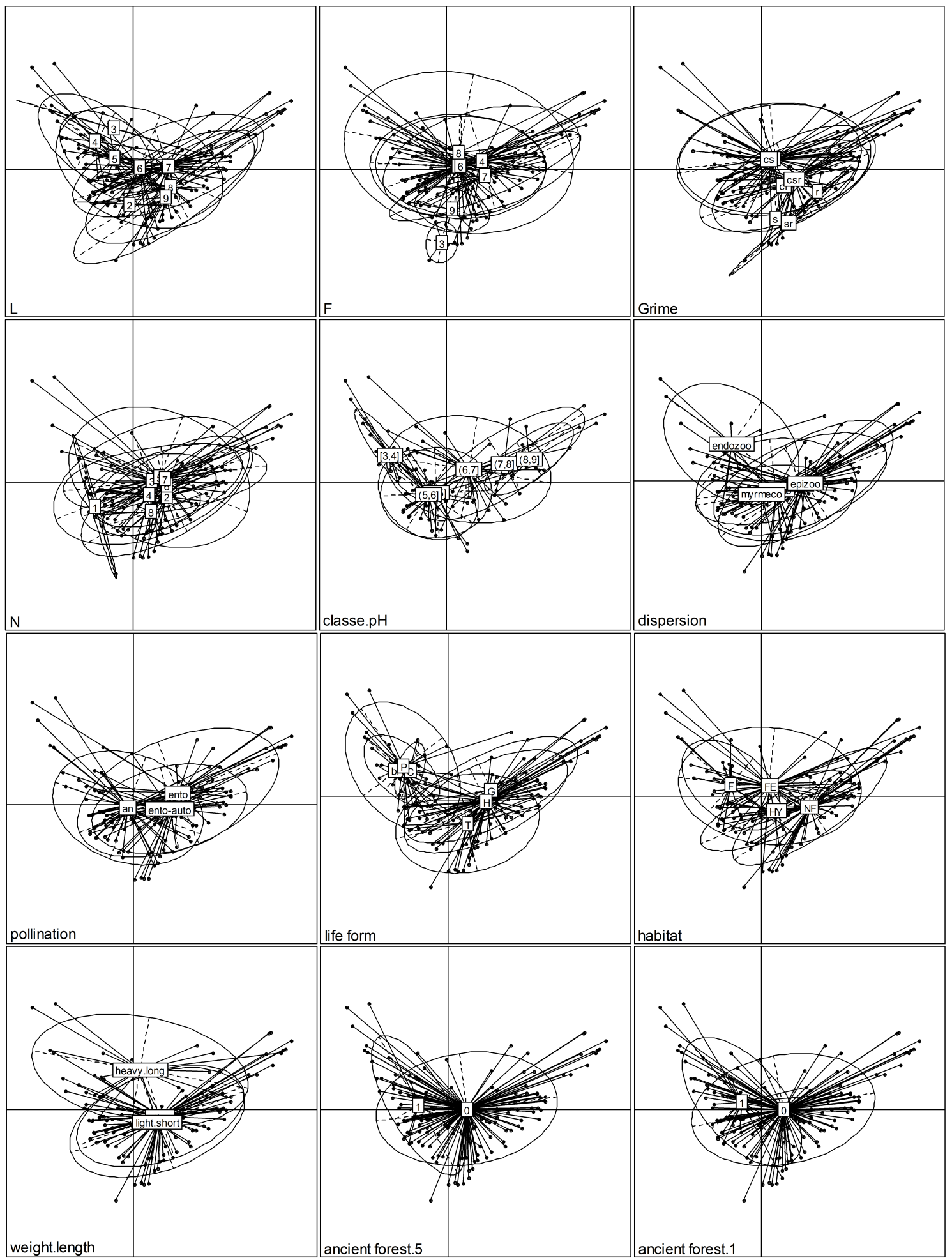

Discrimination of plant communities by biological and ecological traits on factorial map $(1,2)$ of CCA analysis with road distance $x$ STE (skid trail effect) as constraints (224 plots). Species were pooled (centroids) according to their indicator values for light $(L)$, soil humidity $(F)$, nitrogen 
$(\mathrm{N})$ and acidity (pH classes); Grime's strategies; dispersal vector: anemochore (anemo), barochore (baro), endozoochore (endozoo), epizoochore (epizoo), myrmecochore (myrmeco); pollination vector: anemophile (an), entomophile (ento), entomophile-autogame (ento-auto); life form: phanerophyte $(P)$, chamaephyte $(C)$, geophyte $(G)$, hemicryptophyte $(H)$, therophyte $(T)$ plus bryophyte type (bryo); habitat preference: forest species ( $F)$, forest-edge species (FE), non-forest species (NF) and wetland species (HY); weight and length of seeds: $0<$ light $<0.29 \mathrm{~g}$, $0.94 \mathrm{~g}<$ heavy $<7.43 \mathrm{~g}, 0.29 \mathrm{~mm}<$ short $<1.16 \mathrm{~mm}, 1.64 \mathrm{~mm}<$ long $<3.71 \mathrm{~mm}$, intermediate values (other); species of ancient forest referenced in at least one or five studies: ancient forest species (1), non ancient forest species (0). Only categories with a sufficient number of species were considered. 
A. 5

Figure 4.

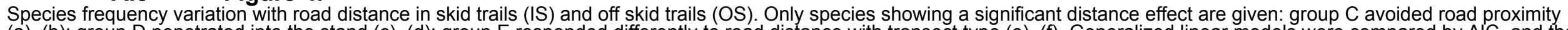

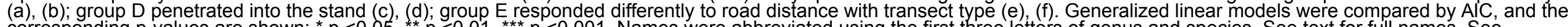
Appendix $B$ for other results.

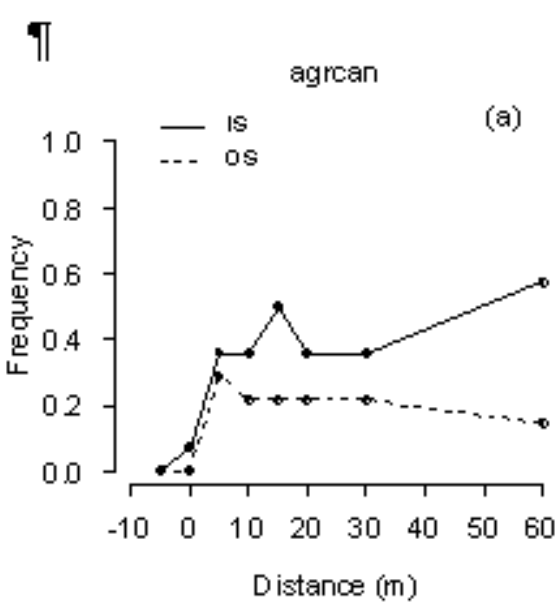

caria

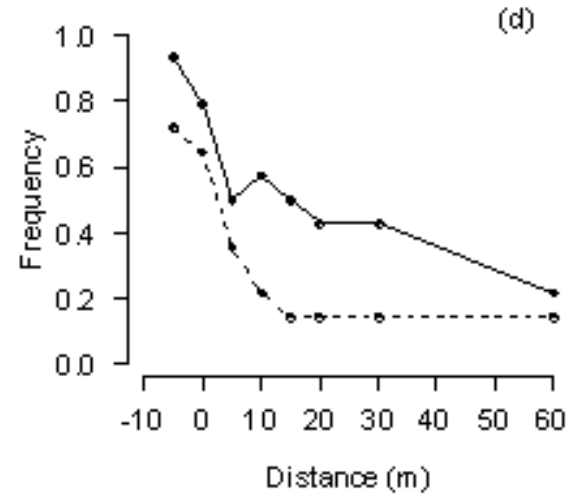

hypoup

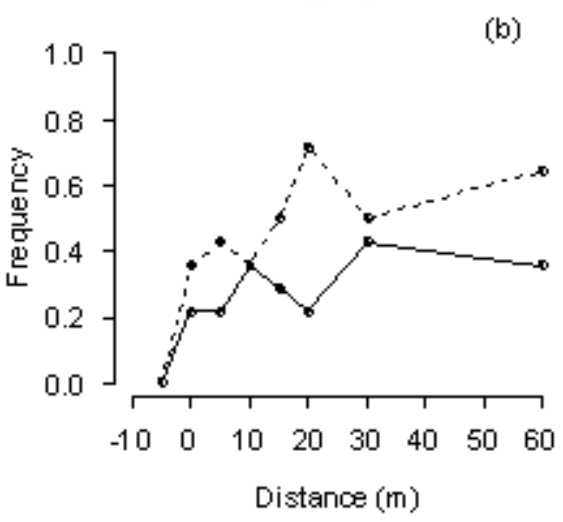

prund

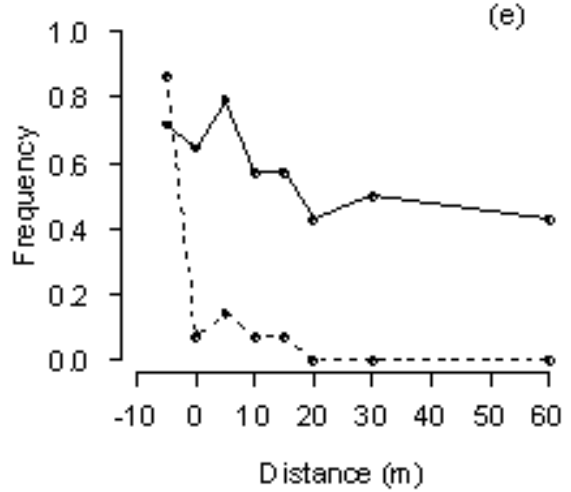

potrep

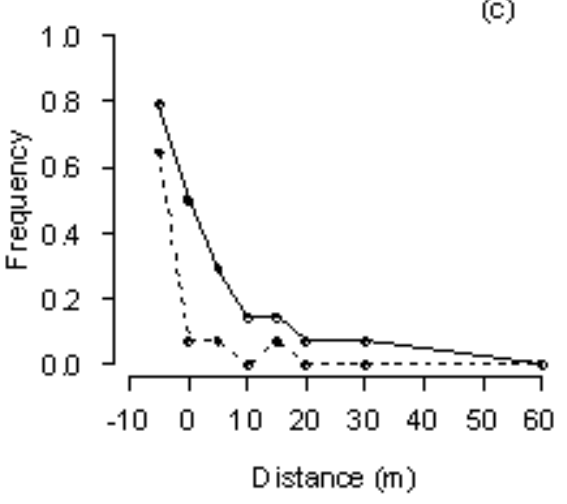

vioriv

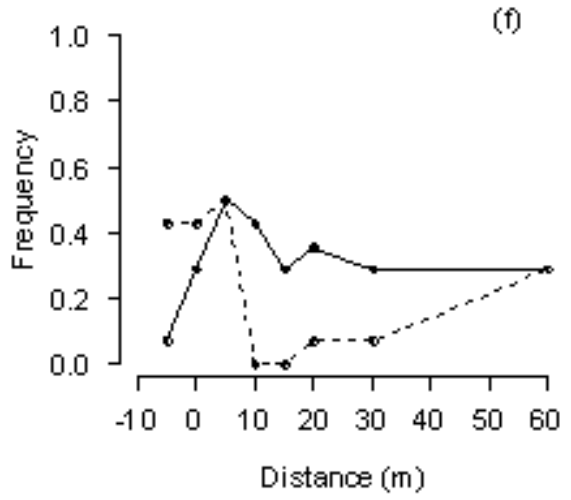


Author-produced version of the article published in Biological Conservation, vol. 159, 2013, 24-31

Original publication available at http://www.sciencedirect.com

doi : 10.1016/j.biocon.2012.10.008

\section{A.6 Appendix A:}

Total number of species according to road distance and type of transect.

$\begin{array}{llllll}\text { Road verge } \quad 0 m \quad 5 m \quad 10 m \quad 15 m \quad 20 m \quad 30 m \quad 60 m & 0\end{array}$

Global analysis

\begin{tabular}{lccccccccc} 
All species & 132 & 143 & 128 & 120 & 114 & 110 & 105 & 97 \\
Unique species* & 18 & 6 & 5 & 1 & 1 & 2 & 3 & 2 \\
\hline
\end{tabular}

Analysis by type of transect

$\begin{array}{llcccccccc} & \text { All species in skid trails } & 111 & 126 & 109 & 108 & 101 & 95 & 89 & 83 \\ & \text { All species off skid trails } & 109 & 80 & 85 & 65 & 64 & 60 & 60 & 65 \\ \text { trails* } & \text { Unique species in skid } & 16 & 7 & 5 & 2 & 1 & 2 & 5 & 4 \\ \text { trails* }^{*} & \text { Unique species off skid } & 35 & 3 & 4 & 2 & 2 & 1 & 1 & 4\end{array}$

*Species only present at this distance. 
A.7 Appendix B:

Effects of road distance, skid trail and their interaction on species frequency for the 50 analyzed species and a posteriori species groups.

\begin{tabular}{|c|c|c|c|c|c|c|c|c|c|c|c|c|c|c|}
\hline Species & STE & Distance & Interaction & Group & IS & os & $\mathrm{RV}$ & $0 \mathrm{~m}$ & $5 \mathrm{~m}$ & $10 \mathrm{~m}$ & $15 \mathrm{~m}$ & $20 \mathrm{~m}$ & $30 \mathrm{~m}$ & $60 \mathrm{~m}$ \\
\hline ajurep & - & - & - & - & 0.15 & 0.08 & 0.14 & 0.21 & 0.18 & 0.14 & 0.07 & 0.04 & 0.04 & 0.11 \\
\hline fraves & - & - & - & - & 0.13 & 0.11 & 0.14 & 0.14 & 0.14 & 0.21 & 0.07 & 0.07 & 0.07 & 0.11 \\
\hline molcae & - & - & - & - & 0.16 & 0.13 & 0.07 & 0.18 & 0.14 & 0.07 & 0.18 & 0.11 & 0.11 & 0.29 \\
\hline sclpur & - & - & - & - & 0.33 & 0.23 & 0.18 & 0.21 & 0.36 & 0.21 & 0.36 & 0.32 & 0.36 & 0.25 \\
\hline carbet & $* * *$ & - & - & A & 0.36 & 0.68 & 0.32 & 0.68 & 0.46 & 0.61 & 0.54 & 0.43 & 0.54 & 0.57 \\
\hline eurstr & $* *$ & - & - & A & 0.05 & 0.16 & 0.00 & 0.14 & 0.11 & 0.11 & 0.11 & 0.07 & 0.18 & 0.11 \\
\hline feshet & * & - & - & $A$ & 0.17 & 0.28 & 0.18 & 0.25 & 0.14 & 0.21 & 0.25 & 0.25 & 0.29 & 0.21 \\
\hline lonper & $* * *$ & - & - & $A$ & 0.22 & 0.45 & 0.14 & 0.39 & 0.50 & 0.32 & 0.32 & 0.36 & 0.39 & 0.25 \\
\hline thutam & $* *$ & - & - & $A$ & 0.12 & 0.26 & 0.00 & 0.21 & 0.14 & 0.29 & 0.25 & 0.21 & 0.21 & 0.18 \\
\hline agrcap & $* * *$ & - & - & $B$ & 0.88 & 0.46 & 0.68 & 0.61 & 0.71 & 0.71 & 0.71 & 0.71 & 0.64 & 0.61 \\
\hline cardem & $* * *$ & - & - & $B$ & 0.17 & 0.04 & 0.14 & 0.04 & 0.11 & 0.11 & 0.18 & 0.07 & 0.00 & 0.18 \\
\hline carpal & $* *$ & - & - & $B$ & 0.40 & 0.24 & 0.14 & 0.29 & 0.29 & 0.29 & 0.32 & 0.43 & 0.36 & 0.46 \\
\hline cenery & $* * *$ & - & - & $B$ & 0.28 & 0.01 & 0.21 & 0.11 & 0.14 & 0.11 & 0.21 & 0.14 & 0.07 & 0.14 \\
\hline hollan & $* * *$ & - & - & $B$ & 0.45 & 0.23 & 0.36 & 0.25 & 0.46 & 0.36 & 0.39 & 0.25 & 0.32 & 0.32 \\
\hline hyprad & $* * *$ & - & - & $B$ & 0.35 & 0.03 & 0.25 & 0.21 & 0.21 & 0.25 & 0.21 & 0.14 & 0.18 & 0.04 \\
\hline juneff & $* * *$ & - & - & $B$ & 0.39 & 0.18 & 0.18 & 0.25 & 0.36 & 0.32 & 0.29 & 0.36 & 0.21 & 0.32 \\
\hline potere & $* * *$ & - & - & $B$ & 0.27 & 0.10 & 0.29 & 0.32 & 0.14 & 0.18 & 0.14 & 0.18 & 0.11 & 0.11 \\
\hline potste & * & - & - & $B$ & 0.16 & 0.06 & 0.14 & 0.18 & 0.18 & 0.18 & 0.11 & 0.07 & 0.04 & 0.00 \\
\hline salcap & * & - & - & $B$ & 0.17 & 0.09 & 0.07 & 0.07 & 0.14 & 0.14 & 0.11 & 0.14 & 0.11 & 0.25 \\
\hline agrcan & $* * *$ & $* * *$ & - & C & 0.32 & 0.16 & 0.00 & 0.04 & 0.32 & 0.29 & 0.36 & 0.29 & 0.29 & 0.36 \\
\hline calepi & - & * & - & C & 0.18 & 0.16 & 0.07 & 0.11 & 0.21 & 0.11 & 0.07 & 0.14 & 0.29 & 0.36 \\
\hline calvul & - & $* * *$ & - & C & 0.23 & 0.24 & 0.00 & 0.14 & 0.18 & 0.21 & 0.32 & 0.36 & 0.36 & 0.32 \\
\hline carpil & - & $* * *$ & - & C & 0.46 & 0.38 & 0.07 & 0.14 & 0.29 & 0.50 & 0.64 & 0.57 & 0.54 & 0.57 \\
\hline cytsco & - & $* *$ & - & C & 0.38 & 0.30 & 0.07 & 0.43 & 0.21 & 0.36 & 0.46 & 0.36 & 0.32 & 0.46 \\
\hline desfle & $* *$ & $* * *$ & - & C & 0.26 & 0.46 & 0.07 & 0.21 & 0.11 & 0.36 & 0.57 & 0.68 & 0.46 & 0.39 \\
\hline dicsco & $* *$ & $* * *$ & - & C & 0.08 & 0.20 & 0.00 & 0.04 & 0.07 & 0.14 & 0.32 & 0.29 & 0.14 & 0.11 \\
\hline hedhel & $* * *$ & * & - & C & 0.15 & 0.47 & 0.21 & 0.61 & 0.32 & 0.32 & 0.29 & 0.21 & 0.36 & 0.18 \\
\hline
\end{tabular}




\begin{tabular}{|c|c|c|c|c|c|c|c|c|c|c|c|c|c|c|c|}
\hline Species & STE & Distance & Interaction & Group & IS & os & $\mathrm{RV}$ & $0 \mathrm{~m}$ & $5 \mathrm{~m}$ & $10 \mathrm{~m}$ & $15 \mathrm{~m}$ & $20 \mathrm{~m}$ & $30 \mathrm{~m}$ & $60 \mathrm{~m}$ & \\
\hline hypcup & ** & $* * *$ & - & $\mathrm{C}$ & 0.26 & 0.44 & 0.00 & 0.29 & 0.32 & 0.36 & 0.39 & 0.46 & 0.46 & 0.50 & \\
\hline hyppul & ** & $* * *$ & - & C & 0.59 & 0.41 & 0.11 & 0.43 & 0.61 & 0.57 & 0.57 & 0.57 & 0.57 & 0.57 & \\
\hline juncon & ** & * & - & C & 0.30 & 0.14 & 0.07 & 0.07 & 0.25 & 0.25 & 0.21 & 0.32 & 0.21 & 0.39 & \\
\hline luzmul & - & ** & - & C & 0.23 & 0.16 & 0.00 & 0.11 & 0.21 & 0.18 & 0.32 & 0.21 & 0.18 & 0.36 & \\
\hline pinsyl & - & * & - & C & 0.13 & 0.21 & 0.07 & 0.07 & 0.18 & 0.32 & 0.14 & 0.29 & 0.11 & 0.18 & \\
\hline polfor & * & $* * *$ & - & C & 0.25 & 0.38 & 0.00 & 0.11 & 0.29 & 0.39 & 0.43 & 0.50 & 0.39 & 0.39 & \\
\hline poptre & * & $* * *$ & - & C & 0.30 & 0.18 & 0.00 & 0.04 & 0.25 & 0.21 & 0.36 & 0.32 & 0.25 & 0.50 & \\
\hline quepet & * & $* * *$ & - & C & 0.62 & 0.73 & 0.29 & 0.68 & 0.54 & 0.75 & 0.79 & 0.86 & 0.79 & 0.71 & \\
\hline rubfru & * & $* * *$ & - & C & 0.68 & 0.80 & 0.46 & 0.96 & 0.82 & 0.61 & 0.82 & 0.79 & 0.64 & 0.82 & \\
\hline verooff & $* * *$ & ** & - & C & 0.54 & 0.13 & 0.07 & 0.25 & 0.29 & 0.46 & 0.50 & 0.46 & 0.36 & 0.29 & \\
\hline brapin & - & $* * *$ & - & $D$ & 0.19 & 0.17 & 0.64 & 0.46 & 0.14 & 0.07 & 0.04 & 0.04 & 0.04 & 0.00 & \\
\hline carfla & $* * *$ & $* * *$ & - & $D$ & 0.55 & 0.31 & 0.82 & 0.71 & 0.43 & 0.39 & 0.32 & 0.29 & 0.29 & 0.18 & \\
\hline cenjac & * & $* * *$ & - & $D$ & 0.15 & 0.06 & 0.32 & 0.21 & 0.07 & 0.11 & 0.07 & 0.07 & 0.00 & 0.00 & \\
\hline dacglo & * & $* * *$ & - & $D$ & 0.35 & 0.23 & 0.75 & 0.57 & 0.32 & 0.21 & 0.21 & 0.14 & 0.07 & 0.04 & \\
\hline hypper & * & $* * *$ & - & $D$ & 0.17 & 0.08 & 0.29 & 0.25 & 0.11 & 0.18 & 0.04 & 0.14 & 0.00 & 0.00 & \\
\hline plalan & $* \star *$ & $* * *$ & - & $D$ & 0.42 & 0.07 & 0.75 & 0.36 & 0.18 & 0.18 & 0.21 & 0.11 & 0.07 & 0.11 & \\
\hline potrep & $* *$ & $* * *$ & - & $D$ & 0.25 & 0.11 & 0.71 & 0.29 & 0.18 & 0.07 & 0.11 & 0.04 & 0.04 & 0.00 & \\
\hline ranrep & * & $* * *$ & - & $D$ & 0.17 & 0.08 & 0.54 & 0.14 & 0.21 & 0.04 & 0.00 & 0.04 & 0.04 & 0.00 & \\
\hline \multirow[t]{2}{*}{ plamaj } & $* * *$ & $* * *$ & $* *$ & $E$ & & & 0.50 & 0.43 & 0.36 & 0.36 & 0.36 & 0.43 & 0.14 & 0.07 & IS \\
\hline & & & & & & & 0.43 & 0.00 & 0.00 & 0.00 & 0.00 & 0.00 & 0.00 & 0.00 & OS \\
\hline \multirow[t]{2}{*}{ pruvul } & $* * *$ & $* * *$ & $* *$ & $E$ & & & 0.71 & 0.64 & 0.79 & 0.57 & 0.57 & 0.43 & 0.50 & 0.43 & IS \\
\hline & & & & & & & 0.86 & 0.07 & 0.14 & 0.07 & 0.07 & 0.00 & 0.00 & 0.00 & OS \\
\hline \multirow[t]{2}{*}{ taroff } & $* \star *$ & $* * *$ & * & $E$ & & & 0.64 & 0.36 & 0.50 & 0.21 & 0.21 & 0.29 & 0.07 & 0.14 & IS \\
\hline & & & & & & & 0.71 & 0.00 & 0.00 & 0.07 & 0.00 & 0.00 & 0.00 & 0.00 & os \\
\hline \multirow[t]{2}{*}{ teusco } & - & $* * *$ & * & $E$ & & & 0.14 & 0.21 & 0.43 & 0.29 & 0.14 & 0.29 & 0.29 & 0.36 & IS \\
\hline & & & & & & & 0.00 & 0.64 & 0.57 & 0.36 & 0.21 & 0.57 & 0.07 & 0.14 & os \\
\hline \multirow[t]{2}{*}{ vioriv } & - & - & $* * *$ & $E$ & & & 0.07 & 0.29 & 0.50 & 0.43 & 0.29 & 0.36 & 0.29 & 0.29 & IS \\
\hline & & & & & & & 0.43 & 0.43 & 0.50 & 0.00 & 0.00 & 0.07 & 0.07 & 0.29 & os \\
\hline
\end{tabular}


Generalized linear mixed-effects models were compared by AIC, and the corresponding $p$-values are shown: * $p<0.05,{ }^{* *} p<0.01,{ }^{* * *} p<0.001$. Names were abbreviated using the first three letters of genus and species. STE: skid trail effect, IS: in skid trails, OS: off skid trails, RV: road verge. For species showing a significant interaction, values were given by skid trail type. 